\title{
[ "The cost of a thing is the amount of what I will call life which is required to be exchanged for it": The Concept of Economy (of Nature) in Thoreau's Walden or Life in the Woods ]
}

\section{Tomáš Jajtner}

University of South Bohemia

České Budějovice, Czech Republic

[Abstract] The present article investigates the notion of economy (of nature) in Thoreau's Walden or Life in the Woods (1854); it introduces the context of coining the concept of economy of nature, presents the challenges of exploring nature in Romantic thought, and finally deals with Thoreau's concept of "economy" as discussed in the first chapter of his opus magnum. Despite its historical grounding in the Romantic tradition and in the tradition of American Transcendentalism, Thoreau's idea of "economy" represents a remarkably fresh version of a sustainable lifestyle, combining scientific observation with profound philosophical and poetic insights.

[Keywords] Henry David Thoreau; ecocriticism; 19th century American prose; Transcendentalism; economy of nature; ecological consciousness 


\section{[1] Introduction}

Henry David Thoreau (1817-1862) is a pivotal player in $19^{\text {th }}$-century American writing and thought; however, he is also one of the key figures who helped define our modern ecological consciousness. His early notes and writings reflect the influence of the crucial "naturalists" of the previous century, the Englishman Gilbert White (1720-1793) and the Swedish biologist Carl Linnaeus (1707-1778), with their focus on the economy of nature, which sought to explain both the complexity of different life forms as well as their fundamental inter-relatedness. Nevertheless, Thoreau's genius develops the idea further and combines "economy of nature" with a complex philosophical reflection on human life which respects the multi-layered and delicate structure of being itself.

The present article explores the breadth and depth of the concept of "economy" in Thoreau's "opus magnum" Walden or Life in the Woods (1854): it looks at the historical con-

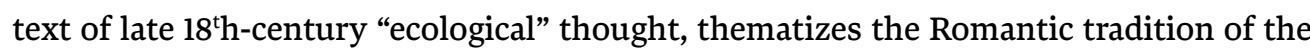
"economy of nature" and discusses the specifics of the Thoreauvian concept. The paper seeks to show Thoreau's remarkably fresh version of a sustainable lifestyle, combining scientific observation with profound poetic insights. In that sense, Thoreau's Walden presents a vital challenge to our contemporary ecological consciousness.

\section{[2] Between Enchantment and Usefulness: Key Models of "Economy of Nature" Prior to Thoreau}

Thoreau is often presented as a "naturalist" (Worster 75), however, the term itself had undergone a remarkable development by the time it came to prominence in the late 1840s. The two towering figures of "ecological" thought in the $18^{\text {th }}$ century, the English curate Gilbert White (1720-1793) and the Swedish biologist Carl Linnaeus (1707-1778), studied not just the "realities and facts" of natural life, but especially the organic unity and the complex web of relations that bind various organisms together.

Gilbert White's genius found its ultimate expression in his Natural History of Selborne (first published in 1789), a work that may be characterized as a collection of letters and several occasional poems "on the wildlife, seasons, and antiquities of White's parish", written in a style "that reminds one of Izaak Walton or Horace Walpole" (Worster 5). White combines a sense of enchantment with the picturesque place where he lives, presenting a series of "scientific" observations dealing with animal behaviour (especially the behaviour of birds), the relation between the different species and the environment, and the description of the mutually beneficial relations amongst the different species. It is a charming report on the joys of scientific discovery as well as a poetic exploration of the beauties of rural life, characterized by direct contact between human and natural elements. 
The concept of the "economy" of nature in White's Natural History of Selborne is primarily derived from the theological meaning of "economy", i.e. from the telos of nature, which finds its climax in an act of adoration of the work of the Creator:

Amusive birds! — say where your hid retreat When the frost rages and the tempests beat; Whence your return, by such nice instinct led, When spring, soft season, lifts her bloomy head? Such baffled searches mock man's prying pride, The God of Nature is your secret guide! (White)

Nevertheless, there is also a different focus that can be discerned in White's observations, namely a clear "economic" interest in the modern sense of the word. For White, the scientific study of biological facts is not a goal in itself; it has to be driven by a different sense of "usefulness". Indeed, such endeavours find their ultimate goal in serving mankind to make the maximum possible profit from their co-existence with the surrounding environment. Thus, in one of the letters “To The Honourable Daines Barrington", dated 2 June 1778, he writes about the need to study vegetation because of the potential economic effect it could have in the future:

Vegetation is highly worthy of our attention; and in itself is of the utmost consequence to mankind, and productive of many of the greatest comforts and elegancies of life. To plants we owe timber, bread, beer, honey, wine, oil, linen, cotton, etc., what not only strengthens our hearts, and exhilarates our spirits, but what secures from inclemencies of weather and adorns our persons. [...] The productions of vegetation have had a vast influence on the commerce of nations, and have been the great promoters of navigation, as may be seen in the articles of sugar, tea, tobacco, opium, ginseng, betel, paper, etc. As every climate has its peculiar produce, our natural wants bring on a mutual intercourse; so that by means of trade each distant part is supplied with the growth of every latitude. But, without the knowledge of plants and their culture, we must have been content with our hips and haws, without enjoying the delicate fruits of India and the salutiferous drugs of Peru. (White)

Thus, the "economic" nature of Creation cannot be simply exhausted by a theological statement on the goodness of all being (cf. "And God saw every thing that he had made, and, behold, it was very good." Gen, 1:31); it is also an invitation to understand its "economic" significance and importance. For White, man is thus not just a vital, sentient part of the "organism of life", but a rational creature called to make the most of the potential advantages of such observations. His concept of "usefulness" is not just the key aspect of all meaningful science or scientific observation: it clearly points to the "economic" and utilitarian bias of much Enlightenment moral philosophy: ${ }^{1}$

Instead of examining the minute distinctions of every various species of each obscure genus, the botanist should endeavour to make himself acquainted with those that are 
useful. You shall see a man readily ascertain every herb of the field, yet hardly know wheat from barley, or at least one sort of wheat or barley from another. (White)

Overall, White's work manifests a duality typical of much $18^{\text {th }}$-century "naturalism“, i.e. the double meaning of pastoralism, referring both to the early pagan "vitalism" (relating the "magic" and "enchantment" of nature to the rites of the various pagan mystery cults ${ }^{2}$ ) and the Christian concept of the Good Shepherd who guards the flock against the wolves (Matthew 18:12-14 or Luke 15:3-7). ${ }^{3}$ In the Christian concept, nature bears the divine image; however, this image is "inanimate", unlike the "animate" soul of humans called to communion with a personal God. ${ }^{4}$ The "economic" aspect thus understands nature as being "for humans", or being shepherded by human beings so that it can yield as much profit as possible.

Carl Linnaeus (1707-1778) developed the idea of the economy of nature more in the direction of traditional taxonomy, i.e. in classifying the different species and relating them to one another. The evolution of his monumental twelve-volume opus magnum Systema Naturae (1735-1768), in which Linnaeus puts forth his acclaimed taxonomic system of classifying various species, was accompanied by numerous other works which sought to give a philosophical gravity to his undertaking. Interestingly, one of these works bears the title Oeconomy of Nature (the original Latin title was Specimen academicum de Oeconomia Naturae). Essentially, it is a work of natural theology; however, it focuses more on the interdependence of the various species, the "inner" logic of nature as displayed in the reconciliation and peace that God intended in creating nature the way $\mathrm{He}$ did. Man's place in the scheme follows the theological concept of imago Dei: man emulates the role of the Creator in observing, understanding, and utilizing nature's produce. "Economy of nature" thus pre-supposes making sense of the inner workings of nature, which allows humans to enjoy the fruits prepared for them by the Creator Himself. Indeed, "by the oeconomy of nature we understand the all-wise disposition of the Creator in relation to natural thing, by which they are fitted to produce general ends, and reciprocal uses" (cf. Worster 37-38). ${ }^{5}$

In that sense, nature's inner logic is decipherable only as long as we take into account its remarkably inscribed and prescribed economy: the law of being is thus the law

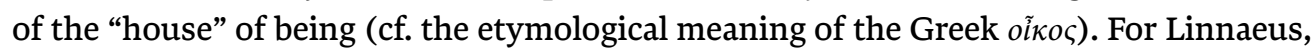
everything that exists, including the very process of nature, is economic, marked by its end "product", i.e. a human being who observes, classifies, and makes use of it:

All these treasures of nature, so artfully contrived, so wonderfully propagated, so providentially supported throughout her three kingdoms, seem intended by the Creator for the sake of man. Every thing may be subservient to his use; if not immediately, yet mediately, not so to that of other animals. By the help of reason man tames the fiercest animals, pursues and catches the swiftest, nay he is able to reach even those, which lye hidden in the bottom of the sea. (Cf. Worster 36)

The emergence of Romantic ecology marks the end of the balanced, rational "economy" of nature as typified in the works of both White and Linnaeus. Nature ceases to be just 
a reflection of the rational divine mind, but is rather a mysterious, wild and "untamed" organism which seems to paint a different picture of what is "natural" for both man and "nature" itself. However, the discontinuity of the paradigm by no means excludes important overlaps and inspirations. In fact, the Thoreauvian genius represents an autonomous synthesis of extensive learning based on earlier and contemporary authors (especially Alexander von Humboldt ${ }^{6}$ and Charles Darwin) and Thoreau's own unique insights into the creative and thus truly poetic force of Nature.

\section{[3] Nature is as well adapted to our weakness as to our strength: Living in Nature as Re- -Creation}

Thoreau's "naturalism" grew out of classical and 18th-century sources (especially the so-called arcadian tradition, with its symbiosis of the natural and human); however, his vision of nature and life "in accordance with nature" is new and original, especially when compared with similar "projects" in the early Romantic period. His decision to leave the company of men and build a cabin near the Walden Pond finds its obvious counterpart in Wordsworth's ideal topos of the Lake District. However, Walden Pond and the Lake District represent two different visions of the cohabitation of the natural and human elements: Thoreau looks for an "untamed", wild nature, where the sheer "civilized" human existence seems to be in desperate need of fundamental justification:

The very simplicity and nakedness of man's life in the primitive ages imply this advantage at least, that they left him still but a sojourner in nature. When he was refreshed with food and sleep he contemplated his journey again. He dwelt, as it were, in a tent in this world, and was either threading the valleys, or crossing the plains, or climbing the mountain tops. But lo! men have become the tools of their tools. The man who independently plucked the fruits when he was hungry is become a farmer; and he who stood under a tree for shelter, a housekeeper. We now no longer camp as for a night, but have settled down on earth and forgotten heaven. We have adopted Christianity merely as an improved method of agri-culture. We have built for this world a family mansion, and for the next a family tomb. The best works of art are the expression of man's struggle to free himself from this condition, but the effect of our art is merely to make this low state comfortable and that higher state to be forgotten. (Thoreau, Walden 989)

For Thoreau, civilization ruins the sense of the original state of humanity, whose nomos is to be taken from studying nature and from the various "natural" processes observable within it. Distancing oneself from civilization creates a space of freedom which allows one to reflect on the realities of the society of the day: in fact, the core arrogance of the contemporary human race is to impose its own nomos on things that seem to have had their own, truly economic and economical "laws". In other words, they are profoundly interrelated with the rest of the living framework from which they have been taken; this 
makes it clear that what seems necessary for most people manifests itself in nature as merely an unnecessary luxury. The very fact that the initial chapter of Walden is called "Economy" thus seems to suggest that its mission is to argumentatively extend the sense of oikos to the inanimate world, whose "usefulness" is not just driven by theological economy ${ }^{7}$ but instead points to the profound consciousness of the universal "gift of Life":

Our manners have been corrupted by communication with the saints. Our hymn-books resound with a melodious cursing of God and enduring him forever. One would say that even the prophets and redeemers had rather consoled the fears than confirmed the hopes of man. There is nowhere recorded a simple and irrepressible satisfaction with the gift of life, any memorable praise of God. All health and success does me good, however far off and withdrawn it may appear; all disease and failure helps to make me sad and does me evil, however much sympathy it may have with me or I with it. If, then, we would indeed restore mankind by truly Indian, botanic, magnetic, or natural means, let us first be as simple and well as Nature ourselves, dispel the clouds which hang over our own brows, and take up a little life into our pores. Do not stay to be an overseer of the poor, but endeavor to become one of the worthies of the world. (Thoreau, Walden 1011)

For Thoreau, "Nature" is not just a place to observe the universally valid rules of life; it is a self-sufficient and self-perpetuating system, "well adapted to our weakness as to our strength" (Thoreau, Walden 974). In an attempt to explain why he set out on such an adventurous experiment, he simply writes that he was too involved and ultimately too dependent on cultural forms: "I determined to go into business at once, and not wait to acquire the usual capital, using such slender means as I had already got. My purpose in going to Walden Pond was not to live cheaply nor to live dearly there, but to transact some private business with the fewest obstacles; to be hindered from accomplishing which for want of a little common sense, a little enterprise and business talent, appeared not so sad as foolish" (Thoreau, Walden 979). In fact, this economic intention is contextualized by numerous references to the philosophical arguments of the past, but also to the paradoxical discovery Thoreau relates to the Indian ways of arranging the necessities of their lives: the more profound attachment they have to the environment (i.e. making their abodes from materials available around them), the deeper is their sense of distance from the solely material substances of life. Indian frugality communicates the simple truth of the passing value of an individual human life:

Consider first how slight a shelter is absolutely necessary. I have seen Penobscot Indians, in this town, living in tents of thin cotton cloth, while the snow was nearly a foot deep around them, and I thought that they would be glad to have it deeper to keep out the wind. [...] Gookin, who was superintendent of the Indians subject to the Massachusetts Colony, writing in 1674, says, “The best of their houses are covered very neatly, tight and warm, with barks of trees, slipped from their bodies at those seasons when the sap is up, and made into great flakes, with pressure of weighty timber, when they are green... The meaner sort are covered with mats which they make of a kind of bulrush, and are also indifferently tight and warm, but not so good as the former... [...]" He 
adds, that they were commonly carpeted and lined within with well-wrought embroidered mats, and were furnished with various utensils. The Indians had advanced so far as to regulate the effect of the wind by a mat suspended over the hole in the roof and moved by a string. Such a lodge was in the first instance constructed in a day or two at most, and taken down and put up in a few hours; and every family owned one, or its apartment in one. (Thoreau, Walden 984)

In fact, Thoreau's aspiration is nothing short of a truly philosophical ambition: his retreat to the Walden Pond can be understood as a withdrawal into the depth of uncertainty in order to restore and recreate a new sense of economy: in other words, once he withdraws from the comfortable yet challenging world of day-to-day worries, he is able to experience the pure and simple enjoyment of life. He thus pleads for an authentic and full-blooded human life in nature: "There are nowadays professors of philosophy, but not philosophers. Yet it is admirable to profess because it was once admirable to live" (Thoreau, Walden 976).

\section{[4] What Are the Necessities of Life?: Pleading for an Authentic and Full-Blooded Human Life in Nature}

As we have seen, the core element of Thoreau's economic thought in relation to nature is a moral indignation at the arrogance of humanity living their lives besides the self-perpetuating and infinitely greater world of nature (or the entire universe). The initial chapter of his Walden is also a very powerful polemic with the so-called "necessities of life" in the "civilized" world. In his typically practical manner, Thoreau lists all the tools, commodities and materials he used to build his thoroughly unconventional existence near the Walden Pond. He identifies the most important needs one has: "Food, Shelter, Clothing, and Fuel" (Thoreau, Walden 975), however, the satisfaction of these needs differs. In fact, our ability to rethink the indispensable necessities of life gives a sense of freshness, a new start and a new re-creation.

Thoreau's discussion of the problem of clothing concentrates on the problem of focus in one's life: clothing in modern civilization represents a fleeting "fashion" and a silly effort to add an extra dimension to one's personality which is not just mendacious, but also redundant and an obstacle to one's integral development:

As for Clothing, to come at once to the practical part of the question, perhaps we are led oftener by the love of novelty, and a regard for the opinions of men, in procuring it, than by a true utility. Let him who has work to do recollect that the object of clothing is, first, to retain the vital heat, and secondly, in this state of society, to cover nakedness, and he may judge how much of any necessary or important work may be accomplished without adding to his wardrobe. Kings and queens who wear a suit but once, though made by some tailor or dressmaker to their majesties, cannot know the comfort of wearing a suit that fits. They are no better than wooden horses to hang the clean clothes on. 
Every day our garments become more assimilated to ourselves, receiving the impress of the wearer's character, until we hesitate to lay them aside, without such delay and medical appliances and some such solemnity even as our bodies. No man ever stood the lower in my estimation for having a patch in his clothes; yet I am sure that there is greater anxiety, commonly, to have fashionable, or at least clean and unpatched clothes, than to have a sound conscience. (Thoreau, Walden 980)

The same essentially applies also to a sound "Shelter": one does not need a great house to live a decent and dignified human life. One needs a "shelter", but a simple one suffices: "However, if one designs to construct a dwelling house, it behooves him to exercise a little Yankee shrewdness, lest after all he find himself in a workhouse, a labyrinth without a clue, a museum, an almshouse, a prison, or a splendid mausoleum instead." (Thoreau, Walden 984). The unnatural and unnecessary need to possess too much, in fact, is one of the reasons why so many people fail to secure "a shelter": paradoxically, the despised Indian "savages" teach us a lesson of how to be sheltered from the vagaries of weather and yet maintain a sense of "economic" freedom. The Indians recognize their fundamental dependency on nature, but they do not owe anybody anything, because Nature has taught them to secure the necessities of life: "But how happens it that he who is said to enjoy these things is so commonly a poor civilized man, while the savage, who has them not, is rich as a savage?" (Thoreau, Walden 985). This implicitly undermines the evaluative element present in the very word "savage": Thoreau thus seems to suggest that "savagery" is in fact the act of inability to calculate the cost in claiming more than what befits a decent person.

The "economic" experience Thoreau undertook in building his existence with minimum initial "pecuniary" input leads to numerous discoveries about the real necessities of life. After all, "the student who wishes for a shelter can obtain one for a lifetime at an expense not greater than the rent which he now pays annually" (Thoreau, Walden 995). The experience of luxury mars our sense of reality: "Kings and queens who wear a suit but once, though made by some tailor or dressmaker to their majesties, cannot know the comfort of wearing a suit that fits" (Thoreau, Walden 980). Indeed, the monetary value of paid tuition is not worth the effort: "Tuition, for instance, is an important item in the term bill, while for the far more valuable education which he gets by associating with the most cultivated of his contemporaries no charge is made" (Thoreau, Walden 996). And the economical reason for artificial transport, i.e. shortening the time spent on the road, proves economically inefficient once the overall cost is taken into account:

One says to me, "I wonder that you do not lay up money; you love to travel; you might take the cars and go to Fitchburg to-day and see the country." But I am wiser than that. I have learned that the swiftest traveller is he that goes afoot. I say to my friend, Suppose we try who will get there first. The distance is thirty miles; the fare ninety cents. That is almost a day's wages. I remember when wages were sixty cents a day for laborers on this very road. Well, I start now on foot, and get there before night; I have travelled at that rate by the week together. You will in the meanwhile have earned your fare, and arrive there some time to-morrow, or possibly this evening, if you are lucky 
enough to get a job in season. Instead of going to Fitchburg, you will be working here the greater part of the day. And so, if the railroad reached round the world, I think that I should keep ahead of you; and as for seeing the country and getting experience of that kind, I should have to cut your acquaintance altogether. (Thoreau, Walden 997)

The core element in the "economy" of Thoreau's sojourn in "nature" is a sense of life whose cost is impossible to estimate or to calculate; the "give-and-take" fundament of any sound economy seems to disregard the cost and the vulnerability of life itself: "the cost of a thing is the amount of what I will call life which is required to be exchanged for it" (Thoreau, Walden 985). This life obviously needs to respect the value of life beyond the confines of merely human endeavours: while the economic logic (i.e. the give-and-take principle) stands, the standard economy of Thoreau's America does not. The reform of the "global" economic consciousness is to do with the simplicity of being one, both in a qualitative as well as a quantitative sense: i.e. being at-one-with Nature, but also just one of the many forms of life the universe has to offer.

\section{[5] Economy of the Universe: Being-at-One with the Universe in the Transcendentalist Context}

Thoreau's economy and ethic of simplicity finds its climax in the poetic vision of binding the fragmented and commodified realities of life. In one of his earlier works, Thoreau makes an ironic reference to A. Pope's Essay on Man (1733): "the proper study of mankind is man." The universe is greater than the essentially petty "philanthropic" interest he attacks in Walden: "The poet says the proper study of mankind is man. I say, study to forget all that; take wider views of the universe. [...] The universe is larger than enough for man's abode" (Thoreau, The Writings of Thoreau 381). This universalist "economy" is not just implicit at the beginning of his Walden. In one of the numerous remarks in his journals, Thoreau makes an immediate reference to the Linnaean concept of the "economy of nature" and extends it into the "economy of the universe". This holistic vision was based on the Transcendentalist tradition of viewing the universe as being permeated by "Oversoul":

Using intuition, rather than reason and science, humans could transcend physical appearances and perceive "the currents of the Universal Being" binding the world together. Thoreau expressed the resulting perception: "The earth I tread on is not a dead, inert mass; it is a body, has a spirit, is organic and fluid to the influence of its spirit. (Nash 36-37)

This holistic view is a locus communis in Transcendentalist philosophy. However, in some respects, it may be argued that there are some differences between Thoreau and his philosophical teacher and friend R. W. Emerson (1803-1882) as regards the fundamental "usefulness" of Nature and its readiness to accept human dominance. Emerson's view in 
Nature (1836) seems to follow the line of the Christian idea of understanding the role of nature as being subservient to the need of the "self-conscious" human species: "Nature is thoroughly mediate. It is made to serve. It receives the dominion of man as meekly as the ass on which the Saviour rode. It offers all its kingdoms to man as the raw material which he may mould into what is useful. Man is never weary of working it up" (Emerson 195). Thoreau, however, rejects the implication based on this view, i.e. the Baconian notion of progress (cf. Worster 106). Thoreau the moralist wishes a thorough immersion in the practical spirituality of everyday life, in that he proves his deep-rootedness in the moral landscape of American Puritanism of the seventeenth century. After all, his frugality "brought his private economy close to nature's economy" (Worster 105): he integrates the human element into the "economy" of the universe that strives to be one with itself. Being responsible is thus essentially identical with being economic(al): being fully conscious of one's moral responsibility is to wish not just the salvation of individual soul(s), but the communion with the entire "Oversoul" radiating the wonderful richness of "Life" that is never spent.

\section{[6] Conclusion}

The concept of "economy of nature" represents an important grounding for the emergence of "ecology" in the 1860s. In the work of Henry David Thoreau, the concept of "economy" includes both the consciousness of the profound dependency of humanity on the resources of the earth (or more concretely, the place where one resides) and the arrogance with which humanity perverts the natural order or imposes its own traditions on the wonderful variety of nature and the universe.

For Thoreau, the idea of economy combines the notion of being (just) a part of a wider whole as well as being economical in dealing with resources. Being at one with nature reinforces a sense of belonging as well as a profound consciousness of the giftedness of one's own existence, whose deepest expression can be found in poetic articulation.

This sense of responsibility, passion for minute observation of natural processes and gift for articulating the poetic "economy of nature (or the universe)" makes the reading of Walden an urgent must-read for a $21^{\text {st }}$-century audience. 


\section{[Notes]}

1 Obviously, "economics" in the $18^{\text {th }}$ century was seen as a branch of moral philosophy, since it fundamentally deals with the problem of good and evil, or with the best possible distribution of various goods in society. The rise of utilitarianism around the middle of the 18th century (cf. Francis Hutcheson's System of Moral Philosophy (published posthumously in 1755, and especially the work of Jeremy Bentham, cf. An Introduction to the Principles of Morals and Legislation) had a major impact on forming the basis of modern economic thought (cf. Adam Smith's Wealth of Nations, 1776). Further contexts can be explored e.g. in A. Roncaglia's Brief History of Economic Thought. Cambridge: Cambridge University Press, 2017, pp. 39-90.

2 Cf. Eliade, Mircea. A History of Religious Ideas: From the Stone Age to the Eleusinian Mysteries. Engl. transl. by W. R. Trask. Chicago: University of Chicago Press, 1978., pp. 264-291.

3 The concept is further discussed in Worster (pp. 26ff).

4 Lynn White, Jr. sees the foundational element of our ecological crisis in Christianity's indifference to inanimate objects: "By destroying pagan animism, Christianity made it possible to exploit nature in a mood of indifference to the feelings of natural objects." White, Lynn Jr. Historical Roots of Our Ecological Crisis, in Cheryll Glotfelty and Harold Fromm, eds., The Ecocriticism Reader: Landmarks in Literary Ecology. Athens: University of Georgia Press, 1996, p. 10.

5 Worster points out that the system itself is basically static and mechanistic: "Essentially, "The Oeconomy of Nature" presents a thoroughly static portrait of the geo-biological interactions in nature. All movement takes place in a single confined sphere, planetary in scope. Like the classical Greek naturalists, Linnaeus allows only one kind of change in the natural economic system, a cyclical pattern that keeps returning to its point of departure. At the very foundation of the natural order is the hydrological cycle, the perpetual circulation of water from the "exhalations" of seas and rivers into the form of rainfall and snow and thence to the sea once more. According to Linnaeus, this model is repeated throughout nature; it is the template or paradigm from which all environmental phenomena take their form; the round of the seasons, the birth and aging of a man, the course of a day, the formation and wearing away of the very rocks" (Worster 34).

6 See e.g. the comprehensive study of Humboldt's contributions to the development of ecological thought in Andrea Wolf's acclaimed monograph The Invention of Nature: Alexander von Humboldt's New World (London: John Murray Publishers, 2015, especially Chapters 19 to 23 ).

7 All there is, is for men: this is aptly exemplified in the "salvation economy" of the divine descent to earth in the Christian theological tradition. 


\section{[Bibliography]}

Eliade, Mircea. A History of Religious Ideas: From the Stone Age to the Eleusinian Mysteries. Engl. transl. by W. R. Trask. Chicago: University of Chicago Press, 1978.

Emerson, Ralph Waldo. Nature in Norton Anthology of American Literature. Volume 1/B. Ninth Edition. Gen. Ed. R. Levine. New York: Norton, 2017. 181-209.

Nash, Roderick Frazier. The Rights of Nature: A History of Environmental Ethics. Madison: University of Wisconsin Press, 1989.

Pope, Alexander. An Essay on Man. Norton Anthology of English Literature. Volume I. Ninth Edition. Eds. M. H. Abrams. and S. Greenblatt. New York: Norton, 2012. 2 714-2 721.

Roncaglia, Alessandro. A Brief History of Economic Thought. Cambridge: Cambridge University Press, 2017.

Thoreau, Henry David. Walden or life in the Woods in Norton Anthology of American Literature. Volume 1/B. Ninth Edition. Gen. Ed. R. Levine. New York: Norton, 2017. 907-1143.

---. The Writings of Henry Thoreau. Ed. Bradford Torrey. Boston, 1906), vol. 14, 306-307.

White, Gilbert. The Natural History of Selborne. (10 September 2021) <https://www.gutenberg.org/cache/epub/1408/pg1408.html>

White, Lynn Jr. Historical Roots of Our Ecological Crisis. In Cheryll Glotfelty, and Harold Fromm, eds. The Ecocriticism Reader: Landmarks in Literary Ecology. Athens: University of Georgia Press, 1996. 3-14.

Wolf, Andrea. The Invention of Nature: Alexander von Humboldt's New World. London: John Murray Publishers, 2015.

Worster, Donald. Nature's Economy: A History of Ecological Ideas. Second Edition. Cambridge: Cambridge University Press, 1994.

\section{[Address]}

University of South Bohemia

Faculty of Arts

Dpt. of English

Branišovská 31a

37005 České Budějovice

Czech Republic

tjajtner@ff.jcu.cz

Dr Tomáš Jajtner is an Assistant Professor of English and American Literature at the University of South Bohemia in České Budějovice, Czech Republic. He holds a PhD in English and American Literature and $a \mathrm{ThD}$ in Catholic Theology, both from Charles University, Prague. His main research interests are early modern English poetry, British conservatism, and ecocriticism. He has published extensively in all the above-mentioned fields. 